\title{
IL-17A producing mast cells as therapeutic target in spondyloarthritis
}

\author{
N Yeremenko ${ }^{1}$, I Gofita ${ }^{1 *}$, T Noordenbos $^{1}$, P P Tak ${ }^{1}$, J Canete ${ }^{2}$, D Baeten ${ }^{1}$ \\ From 5th European Workshop on Immune-Mediated Inflammatory Diseases \\ Sitges-Barcelona, Spain. 1-3 December 2010
}

\section{Introduction}

We recently observed a remarkably increased synovial infiltration with c-kit-positive mast cells in non-psoriatic and psoriatic spondyloarthritis $(\mathrm{SpA})$ versus rheumatoid arthritis (RA).

\section{Aim}

As these mast cells were not degranulated, we investigated whether they could contribute to synovial inflammation by cytokine production, with special focus on IL-17.

\section{Patients and methods}

Synovial tissue biopsies from active non-psoriatic and psoriatic SpA $(n=10)$ and RA $(n=10)$ were stained with mouse anti-c-kit, goat anti-IL-17 and mouse anti-mast cell tryptase (MCT) by immunohistochemistry and double immunofluorescence. The effect of inhibition of c-kit tyrosine kinase by imatinib mesylate on proinflammatory cytokine production was tested in vitro on fresh synovial biopsies from 14 SpA patients.

\section{Results}

Mast cells were identified in synovial tissue by immunostaining for c-kit or mast cell tryptase. Single immunostaining for IL-17 showed multiple single positive mononuclear cells in all types of arthritis. Double immunofluorescence indicated a striking colocalization of IL17 and mast cell tryptase in non-psoriatic and psoriatic SpA. Quantification by manual counting confirmed that a median of $65 \%$ of the synovial mast cells in SpA express IL-17. In contrast, only $26 \%$ of the mast cells expressed IL-17 in RA ( $\mathrm{p}=0.015)$. Moreover, mast cells were the main IL-17 producing cell subset in SpA (60-70\%) but not in RA $(20-30 \%)(p=0.036)$. In order to investigate the

Clinical Immunology and Rheumatology, Academic Medical Center/ University of Amsterdam, The Netherlands

Full list of author information is available at the end of the article role of cytokine production by mast cells in the synovial inflammation in SpA, we used imatinib mesylate to block c-kit tyrosine kinase in ex vivo synovial tissue cultures. C-kit blockade strongly reduced not only IL-6 and IL-8 but also IL-17A production by SpA synovial biopsies.

\section{Conclusion}

The increase in synovial mast cells in SpA synovitis, their augmented production of IL-17, and the downregulation of cytokine production by targeting mast cells ex vivo strongly suggest that mast cells contribute to synovial inflammation in SpA and are an attractive therapeutic target.

\section{Author details}

${ }^{1}$ Clinical Immunology and Rheumatology, Academic Medical Center/ University of Amsterdam, The Netherlands. ${ }^{2}$ Rheumatology, Hospital Clinic Barcelona, Spain.

Published: 25 November 2010

doi:10.1186/1479-5876-8-S1-P42

Cite this article as: Yeremenko et al:: IL-17A producing mast cells as therapeutic target in spondyloarthritis. Journal of Translational Medicine 2010 8(Suppl 1):P42.

Submit your next manuscript to BioMed Central and take full advantage of:

- Convenient online submission

- Thorough peer review

- No space constraints or color figure charges

- Immediate publication on acceptance

- Inclusion in PubMed, CAS, Scopus and Google Scholar

- Research which is freely available for redistribution 